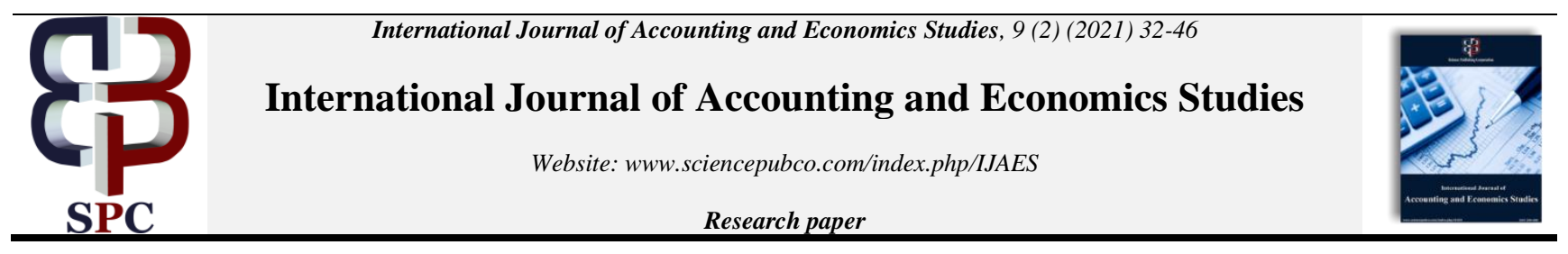

\title{
Brand promotion cost outlay on financial performance of telecommunications industry in Nigeria
}

\author{
Hwerien Rosemary Idamoyibo * \\ Department of Accounting, Ignatius Ajuru University of Education, Rumuolumeni, PMB 5047, Port Harcourt, Rivers State, Nigeria \\ *Corresponding author E-mail: idamoyibohwerien@gmail.com
}

\begin{abstract}
This study ascertained the impact of brand promotion cost outlay on financial performance of telecommunications industry in Nigeria. The research adopted ex-post facto research design and makes use of secondary sources of data. The population of the study comprised the four telecommunications network providers in Nigeria, MTN, GLO, 9Mobile, and Airtel. The study makes use of all the four telecom-munications providers in Nigeria as its sample and obtained the data from their annual financial reports. The study employed the technique of ordinary least square (OLS) based on panel regression analysis. The findings showed that AC increased by a unit percentage, the ROA decreased by -4.1 units; SC increased by a unit, the ROE decreased by -6.7 units; while CE increased by a unit, the PRM increased by -4.3 units, vise visa. The study showed a positive and significant impact of advertising cost on return on asset, positive and significant impact of sales cost on profit margin, positive and significant impact of celebrity endorsement cost on profit margin over the period. The study, therefore, concluded that there is a positive and significant impact of brand promotion cost outlay on financial performance of telecommunication industries in Nigeria.
\end{abstract}

Keywords: Brand; Promotion Cost Outlay; Financial Performance; Telecommunications Industry in Nigeria.

\section{Introduction}

Telecommunication networks have enormously changed the way we conduct business in Nigeria. The life of the poor people has been affected by these great changes. The Nigeria Telecommunication Limited (NITEL) was founded in the year 1985 to aid the country in the improvement of the telecommunication industry. The telecommunications industry in Nigeria was undersized pending the deregulation of the industry in the year 1992 and the establishment of the Nigerian Communications Commission. Since the introduction of telecommunication networks, they have experienced considerable acceptance worldwide. The Global System for Mobile Communication (GSM) in Nigeria is noticeable to the deregulation of the Telecommunications industry which gave birth to the GSM Revolution from the year 2001 under the civilian administration of President Olusegun Obasanjo, GCFR. Since then, the GSM has witnessed a phenomenal growth in the number of subscribers from barely over one hundred million $(100,000,000)$ subscribers (Nkordeh et al., 2017). The investigation carried out on the rebased Gross Domestic Product (GDP) statistics disclosed that the telecommunications industry has accounted for $8.69 \%$ of six trillion, nine hundred and seventy million ( $\$ 6,970,000,000)$ of the Nigeria total GDP (Akintola et al., 2015). According to the Nigeria communications commission (2020) the telecommunication industry subscriber statistics revealed that the industry has an active lines of one hundred and ninety nine million, three hundred and seven thousand, seven hundred and ninety six $(199,307,796)$ and connected lines of two hundred and eighty six million, five hundred and twenty two thousand, nine hundred and twenty six $(286,522,926)$ as at April, year 2017 to July, year 2020 which showed that it has an impact in the revenue generation of the Nigeria economy.

Before the advent of Global System for Mobile Communication (GSM), the Nigeria Telecommunication Limited was saddled with the responsibility of providing means of communication, basically the Landline which was bedeviled by gross inefficiency and corruption. ECONET (Airtel) was the first GSM network provider that came into Nigeria, it was formally launched on $6^{\text {th }}$ August, year 2001 and followed by MTN, Globacom (Glo) and Etisalat (9 mobile). In Nigeria, the GSM revolution has enhance the Information and Communications Technology (ICT). Since the introduction of the GSM, mobile networks have swiftly become the general way of voice communication in Nigeria with the aid of mobile phone. The growth of the industry has been so swift that Nigeria has been mentioned in various media as "one of the fastest rising GSM markets in the world". These developments have been actually explosive: according to the year 2004 statistics of the Nigeria Communication Commission compared to about four hundred and fifty thousand $(450,000)$ working lines of NITEL in the year 2001. Around August in the year 2004, the GSM operators had recorded over seven million $(7,000,000)$ subscribers. In fact, as at April year 2008 the number of telephone lines were put at about forty two million five hundred thousand $(42,500,000)$ lines, forty two million $(42,000,000)$ was credited to GSM and five hundred thousand $(500,000)$ to Code Division Multiple Access (CDMA). Each of these telecommunication networks have been developing over time, based on successive influenced of innovation, such as wireless "generations" (second (2G) mobile cellular networks, third (3G) mobile cellular networks, forth (4G) mobile cellular networks, and fifth (5G) mobile cellular networks (International Telecommunication Union (ITU), 2020, p1-35).

The floor of mobile telecommunication is not just about GSM or CDMA, companies like GLO mobile and MTN already operating Third Generation Telephone Technology (3G), Fourth Generation of mobile Technology (4G), General Packet Radio Service (GPRS) and High 
speed packet Access, the upgraded version of 3G mobile networks. Considering, therefore, the number of communication network brands in Nigeria and the importance of sales to the various manufacturers, it is expedient for organizations to engage in programmes that can influence consumer's decision to purchase their products (Obiekwe, 2012).

\subsection{Statement of the problem}

Nigeria has one of the world's fastest growing telecommunications market in which there are numbers of brand of communication networks that compete for market leadership. As a result, advertisers', sales promotion and brand ambassadors' objectives are to reach prospective customers and influence their awareness, attitude and buying behaviour. Advertising, sales promotion and brand ambassadors affect consumers' day-to-day lives, enlightening them about products and services and influencing their attitudes, beliefs and eventually their purchase (Lamb et al., 2004). Consumers have had difficulty in choosing a brand of communication networks because there are various factors that influence them in choosing a specific communication network brand. The factors in choosing a particular brand include consumer income, price, cost of call rate, network reception, speed of online access, availability of network coverage, network bonus such as data and airtime, quality service like customer care, available substitutes, and social institutions, etc. Brand preference does exist in the telecommunication industry and a lot of consumers do not just buy whatever is offered, however reasonable, even if it is of good value for its price. There is a huge competition between the telecommunication network providers, and with the features or benefits which consumers want to achieve before purchasing a brand of network, telecommunication network providers now spent huge amount of money to promote their products and services by using advertisers, sales promotion and brand ambassadors, in order to influence customers in patronizing their brand of communication networks. However, in promoting these brands, there are huge costs attached. Therefore, one wants to know whether after expending these costs, the telecommunication network providers will meet goals of financial performance.

\subsection{Objectives of the study}

The general objective of this study is to ascertain the impact of brand promotion cost outlay on financial performance of telecommunications industry in Nigeria.

The specific objectives are to:

i) Ascertain advertising cost of telecommunications industry on Return on Assets;

ii) Investigate sales promotion cost in telecommunications industry on Return on Equity;

iii) Ascertain the cost of endorsing celebrities as brand ambassadors in telecommunications industry on profit margin.

\subsection{Research hypothesis}

The following research hypotheses were formulated for this study:

i) Advertising cost in telecommunications industry does not have positive and significant impact on Return on Assets

ii) Sales promotion cost in telecommunications industry does not have positive and significant impact on Return on Equity

iii) Endorsing cost on celebrities as brand ambassadors in telecommunications industry does not have positive and significant impact on profit margin.

\subsection{Concept of brand}

Brand is a name of a design, sign, symbol, term or a combination of all of these that is used to identify products or services of a person or group of sellers and to differentiate it from the competition or can also be related to appointments, acceptance, trust and expectations of sellers to consistently provide the features and benefits of certain services to the buyer. There are five levels of understanding a brand such as attributes, benefits, values, culture, personality or users. Every consumer purchases have certain expectations of the products that he or she uses and satisfaction is the expected result. Customer satisfaction is dependent on the assumption of product performance in delivering value relative to the expectations of the buyer. When performance or achievements exceed expectations, the buyer is satisfied. The consumer dissatisfaction arises when the results do not meet consumer expectations. Consumer dissatisfaction is one factor contributing to the brand switching behaviour of consumers because dissatisfied customers will look for another product or service, and will probably stop buying products or services or influence others not to buy. The indicators that can be used are the values, benefits and desires. Brand Loyalty is a measure of customer's loyalty to a brand. Brand loyalty is the willingness of consumers to stick to a brand when competitors come up with offers that are equally interesting, not because of the history of the consumer and the brand. Most writers and researchers focused more on the behavioural aspects of brand loyalty and focused less on aspects of brand loyalty (Susanti, 2015).

\subsection{Advertising and promotion}

The packaging of a product or its price does not change the fact that if the product is not known by the potential customers, there is a low possibility of meeting sales target at the end of the year. This is where advertising and promotion are very relevant. Advertising and promotion refer to activities undertaken to increase sales or develop the image of a product and the organization. As a promotional strategy, advertising serves as a major tool in creating product awareness and conditioning the mind of a potential consumer to take purchase decision. Advertising is a sole component of the marketing process. It is the part that involves getting a word out concerning your business, product or the services you are offering to your customers; it involves the process of developing strategies such as ad placement in the media like newspaper, direct mail, billboards, television, radio and of course the internet to influence your products. Promotion, on the other hand, is a more short-term strategy. Promotion helps to build sales in a short term. Promotions include coupons in the local paper, free-samples or two-for-one specials. Advertising is define as a communication process, a marketing process, an economic and social process, a public relations process or an information and persuasion process (Arens, 1996). Advertising referred to any paid form of non-personal communication about organization, product, service or idea by a well-known sponsor (Belch \& Belch, 2001). Ezirim et al. (2004) posit that advertising is a direct effort at creating and/or increasing customers' patronage. The effort comes in form of messages, which influence the emotional, physiological, and psychological need states of the customer. This automatically changed the customer's buying behavior by developing preference for the product or service being advertised. According to Wikipedia, the free online encyclopedia, advertising is a form of communication planned to convince an audience (viewers, readers or listeners) to purchase or take some action upon products, ideas and services. It comprised the name of the products or services and how the products or services could benefit the consumer, to 
convince a target market to purchase or to consume a particular brand. Onah and Thomas (2004) describe advertising as the profession whose members plan, prepare and place sales message in the mass media to win patronage for goods, services or ideas. They also argue that the tasks of promotion include to "communicate with the consumer and provide him or her with information which will lead him or her to use the product or service; provide him or her with enough incentives that would induce him or her to accept the product; and offer him or her invitation for immediate action.

Achumba (2000) identifies the following as the possible objectives of advertising. According to him, they include to inform, persuade, remind, support personal selling programmes; reach people who are inaccessible to salesmen; increase sales of product/service; long-term build-up of firm's corporate image; long-term build-up of a particular brand; information dissemination about a product, sales, service or idea; announcement of special sale and the advocacy of a particular cause. The definitions above show that the aim of advertising and promotion is to create awareness of the advertised product and provide information that will assist the consumer to make purchase decision. The impact of advertising and promotion, therefore, depends greatly on its ability to persuade consumers not only to buy, but to continue to buy until they become loyalists of the brand.

\subsection{The use of celebrities as brand ambassadors in advertisements}

Celebrities are used by manufacturers to create brand identity and on a long run, stimulate purchase. Dixs and Pougnet (2009), in their research, found that Nollywood and Athlete role model endorsement has a positive influence on young adults' brand switching behaviour, complaint behaviour, positive word-of-mouth behaviour and brand loyalty. According to them, this confirms the assumption that actors, actresses and sports celebrities are important socialization agents and can have significant impact on purchase intentions of brand switching and behaviours. They argue that it is crucial that organizations/manufacturers be mindful of the risks associated with using celebrities to endorse their products and opine that good examples of celebrity brand ambassadors are Chelsea FC of England players, Mikel Obi, Dider Drogba, Michael Essien, Yaya Toure; pop music artistes, David Adedeji Adeleke (Davido), 2Face Idibia the Legendary Nigerian artiste and Headlinear of the Hennessey Artistry 2014; Nollywood actors and actresses, Funke Akidele, Eniola Badmus, Francis Odega, Ice Prince, Seyi Shay, Genevieve Nnaji, Olamide Omawumi, and M. I. Abaga who are brand ambassadors for various telecommunication networks. Young people who see these players, musicians, actors and actresses as role models tend to make a purchase and also switch brands that are associated with them. Most authors have noted that a decline in the celebrity's image can impact the image of the brand. So it is essential to choose a celebrity who currently has a good image and will likely be able to uphold this image in the future.

\subsection{Philosophy and theoretical framework}

This study is hinged on deductive philosophical approach and the resources based view theory. Penrose's (1959) study is marked as a base of resources based view of firm. She theorized the firm as a managerial organization and a collection of productive resources. She differentiated physical and human resources and latter include the knowledge and experience of the management team. Wernerfelt (1984) opines that resources based view serves at its foundation that a resource is something which could be understood as a strength or weakness of firm's performance, whose tangible assets are tied semi-permanently to the firm. Resources based view theory was promoted by Barney's (1991) work, in which he identified four qualities of resource through which a firm can achieve continuous competitive advantage. Barney redefined resource as all assets, experiences, administrative processes, firm attributes, information and knowledge that is controlled by a firm and which facilitate it to consider and implement strategies that increase its efficiency and effectiveness. Resources are of three major types, such as physical, human and organizational. Resources based view could be useful in the context of brand promotion and sale promotion processes. The process should not be seen as a resource and experience, but as the brand and sales promotion process that could be a technique to evaluate firm's resources and experiences which will lead to competitive advantage. Competitive advantage originate from cost advantages where a product could be offered at a lower price or through differentiation where an exceptional product can command a higher price. A firm is required to meet a range of resource and competence requirements such as access to capital, specialization of jobs and functions, creativity and strong cross-functional coordination (Porter, 1980). Before resources and experiences can be used, they need to be identified and evaluated. Resources are classified as tangible assets which include employees, training and qualifications, while experiences arise through organizational functions which include corporate, physical, financial and intangible assets e.g. technology and reputation; human resources management, research and development; sales, marketing and manufacturing. The prospective resources and competences to accomplish either cost advantages, differentiation, or competitive advantages depend on some factors like brand promotion, mobility, durability and embeddedness of resources. The evaluation through standing and comparative strength of resources and competences can facilitate a firm to make use of these advantages. Brand promotion process is an instrument used for evaluations; it is used to set performance targets and distribute resources to achieve anticipated targets (Ezinne et al., 2017).

\subsection{Empirical review}

Ezinne et al. (2017) investigated the association between corporate planning and performance of telecommunication companies in Makurdi, Benue State, Nigeria. They found that the problem of inadequate information during planning on the strengths and weaknesses of the organizations, faulty definitions of organizational goals, poor plan implementation, control and review have made telecommunication companies in Nigeria to meet their expectation. The population of the study comprised one hundred and thirty three (133) senior staff with working experience. Correlational survey research design was adopted for the study. Data was obtained for the study using a validated questionnaire structured on a 5-point rating scale. The data was analyzed with the application of Statistical Package for Social Sciences (SPSS) software version 20.0. The finding showed that strategic analysis has significant association with customer satisfaction in telecommunication companies, and there is a significant association between strategic objective and market share in telecommunication companies. Pan et al. (2014) investigated the association between corporate social responsibility and financial performance in the mineral industry: evidence from Chinese mineral firms. The study examined the association between corporate social responsibility and corporate financial performance using panel data of two hundred and twenty eight (228) Chinese mineral listed firms for the period 2010 to 2013 and the study employed pooled least square regression analysis. The study focused on six (6) diverse sublevels of corporate social responsibility such as shareholder responsibility, employee responsibility, environmental responsibility, public responsibility, supplier responsibility, and customer and consumer responsibility for understanding the effects of corporate social responsibility basics on financial performance. The finding revealed that corporate social responsibility has important effects on Return on Asset, Return on Equity, and Earnings per Share, which specify that corporate social responsibility subjects may benefit a company in terms of cost reductions, thus it would lead to a profit increase. Adebayo et al. (2012) evaluated the influence of corporate social responsibility reporting and financial performance of money 
deposit banks in Nigeria. The researchers discovered the importance and practice of corporate social responsibility in relation to its influence on profitability (return on assets and return on equity) of Money Deposit Banks in Nigeria. Five (5) banks were selected randomly from the banks that appeared successfully throughout consolidation. The study used regression and co-efficient of correlation analysis to analyzed the data. The study findings showed that local firms observed and partook in corporate social responsibility as business philanthropy. It also revealed that the performance and reporting of corporate social responsibility has a significant association with profitability dimensions of return on assets of the banks, while the performance of corporate social responsibility reporting has no relationship with return on equity. The study proved that performance and reporting of social responsibility bring improvement to the reputation, sales and profit level of firms working in Nigeria.

Doob et al. (1969) used a field experimental approach whereby new brands of frequently purchased consumer products were introduced in several commercial shops. In some of the commercial shops, the brands were sold at a discounted price, while in the control commercial shops these brands were sold at the regular price. After the introductory period, the discounts were withdrawn in the experimental commercial shops, therefore, matching the prices that were charged all commercial shops. Over subsequent period, a fast reduction in sales was observed for those experimental commercial shops where the discount was withdrawn. Remarkably, following the discount refutation, total sales in the control commercial shops were greater than those in the experimental commercial shops although during the discount period the opposite pattern was observed. Agu et al. (2020) studied the determinants of telecommunications sector contributions to domestic output in Nigeria. The study examined the determinants of telecommunications sector contribution to domestic output in Nigeria for the period 1986 to 2018. The macroeconomic variables such as contribution of telecommunications sector to gross domestic product (CTGDP0, Gross Fixed Capital Formation, Degree of Openness and Foreign Direct Investment in telecommunications sector (FDIT) was used. The study made used of time series and ex-post facto research design and the data were sourced from CBN Statistical Bulletin, CBN Annual Report and Statement of Accounts (2004, 2007 and 2017) and the quarterly data for the period 1986Q1 to 2018Q4 were sourced from World Bank Development Indicators, National Bureau of Statistics and Central Bank of Nigeria annual publications. The study employed the Autoregressive Distributed Lag (ARDL) model and bounds test approach of co-integration that was developed by Pearsan, Shin, and Smith 2001, with the application of econometric package E-view software version 10 to estimate the model. The findings showed that at long-run evaluation foreign direct investment, institutional framework and labour force have positive and significant impact on the growth of telecommunications sector. Exchange rate, mobile phone subscription, trade openness proves otherwise, however gross fixed capital formation, medium and high-tech exports remain not significant in the long run. The speed of adjustment at which equilibrium is restored at any one point during disequilibrium is seven point thirty five percent $(7.35 \%)$. The chow test showed that deregulation have significant impact on growth of the telecommunications. Toda Yamamoto Granger-causality test result revealed that there is a bi-directional relationship between foreign direct investment and telecommunications GDP.

Grigoriou et al. (2018) examined previous unexplored antecedent factors determining brand switching behavior of mobile telecommunications consumers, and relative significance of those factors. The study adopted deductive approach to facilitate the management and the analysis of data. The study made use of primary sources of data collections in a multi country study and the dataset comprised twenty four thousand, one hundred and forty one $(24,141)$ respondents from four $(4)$ countries. The whole respondents were of adult age and has once purchased a mobile telecommunications plan with their preferred service provider. The sampling were selected via an online survey using a consumer panel of a global panel company. The countries in this study were selected based on their economic development (two developed economies, and two emerging economies) for comparison purposes. The data were obtained via an online survey over a four (4) months period in the year 2014. The data was weighted by the market size of the telecommunication brands. The number of telecommunications brands covered in each country is wide-ranging between three (3) and seven (7) which are China: 3 (China Mobile, China Unicom, and China Telecom), India: 7 (Airtel, Vodafone, Reliance Communication, Idea, BSNL, Aircel, and Uninor), Japan: 5 (NTT Docomo, KDDI Mobile, SoftBank Mobile, EMOBILE, and Willcom), and USA: 6 (AT\&T, Verizon, Sprint, T-Mobile, Cellular One, and US Cellular). The study identifies the whole dimensions of the switching behavior and then validated a theoretical model. The regression model suggests weak coefficient of determination (R2) between the dependent and independent variables. Adeleke and Aminu (2012) investigated the determinants of customer loyalty in the GSM market in Nigeria. The study made used of primary sources of data with the aid of questionnaire. Total of two hundred and fifty two (252) questionnaires were self-administered to the subscribers of the four major GSM providers in Lagos State in which one hundred and ninety eight (198) of properly filled questionnaires were returned. The study employed Pearson Product Moment Correlation with the help of statistical package for social sciences (SPSS) software version 17 to analyze the data. The findings shown that service quality, customer satisfaction, and corporate image are important determinants of customer satisfaction and loyalty in the Nigeria's GSM market. The fourth factor, price/tariff is found not to be a determinant of customer satisfaction and loyalty in market. The study concluded therefore that GSM companies should emphasize on the factors influencing customer satisfaction and loyalty in their marketing strategy.

Scott (1976) experimentally manipulated the magnitudes of incentives such as free newspaper, half price of a newspaper and full price of a newspaper to inspire a two-week trial of a newspaper. She observed that there is a curvilinear association between the trial rate and the amount of incentive when the incentive was withdrawn. However, very substantial incentives resulted in a low rate of subscription to the newspaper when the offer was withdrawn. Significantly more users subscribed in the half price condition than those that subscribed in a control group composed of users who had not received the 2 -week trial offer. The difference in the subscription rates of the full price condition and the no trial condition was insignificant. Olotewo (2017) conducted a study on analyzing the moderating effect of customer loyalty on long run repurchase intentions. The study investigated the moderating effect of consumer loyalty on long-run repurchase intentions in telecommunication industry using Lagos State environment as a study. The study adopted field survey research design using questionnaire to gathered data from two hundred and fifty (250) respondents. The respondents were selected using random and stratified random sampling techniques from the telecommunication industry in Lagos State, Nigeria. The reliability of the research instrument was verified using the result of Cronbach's alpha of zero point eighty nine percent (89\%), this showed that the survey instrument was reliable. The study used Pearson Product Method of Correlation (PPMC), simple regression analysis and inferential statistics to analyze the data with the application of the Statistical Package for Social Sciences (SPSS) software version 20 to test the hypotheses. The findings of the study revealed that customer satisfaction has a significant relationship with customer loyalty in the telecommunication industry. Also, service quality has a significant relationship with customer loyalty to a brand; loyalty programs have a significant relationship with customer loyalty to a network operator in Nigeria and customer loyalty has a significant effect on the long run repurchase intentions of the customer. The study concluded therefore that one of the determinants of long term profitability of a business entity is the long run repurchase intentions of its customers which hinged on the level of brand loyalty of the customer.

Abdullahj et al. (2015) examined the effects of standard costing on the profitability of MTN telecommunication companies to discover if the application of standard costing techniques have any effect on profitability, to explore the relationship between standard costing and the profitability of telecommunication companies and determining whether standard costing techniques and principles are being adopted and 
practiced by Nigerian MTN Telecommunication Company. The study made used of secondary data and interviews method for instrument of data collection and employed descriptive survey design. The findings of the study revealed that accounting records are kept and were significantly necessary in the management of the company. Furthermore, the company employed standard costing in their product, and decisions were made with the standard costing information obtained in the company. Again, the accounting reports are prepared and presented to the company's management and actions were taken promptly on the information given in the report. In addition, effective application of standard costing has effect on the profitability of the company and the company benefit in a significant way through the use of standard costing especially in the improvement of profit. The study concluded that standard costing is widely used in Nigerian telecommunication companies and standard costing enhances adequate planning, control and decision making processes in the company, and also standard costing helps telecommunication companies in dismissing of unprofitable products, provision of costing information and cost control. Afzal et al. (2013) examined the diverse factors which lead users to brand switching, brand loyalty of users with preferred cellular networks and ratio of usage of the cellular network. The study made used of primary data for data collections and the population of the study comprised one thousand and forty eight (1048) respondents, and seven hundred and thirty eight (738) were from Shaheed Mohtarma Benazir Bhutto Medical University Larkana (SMBBMU), while three hundred and ten (310) were from Shaheed Zulfiqar Ali Bhutto Institute of Science and Technology Larkana (SZABIST). The sample size of study is taken from larkana city. The sample size is made up of three batches of SMBBMU, BBA \& MBA students of SZABIST. The sample respondents were choosing through convenience sampling technique and the overall sample size is one hundred and four (104). The networks are Ufone, Telenor, Mobilink, Warid and Zong in Pakistan. The employed regression analysis to analyze the data with the help of statistical package of social sciences (SPSS). The findings revealed that service quality does not influence customers to switch the network. The findings further showed a positively relationship between price and brand switching. It also revealed a positive relationship between the trust and the brand switching. However, brand loyalty has a negative impact on brand switching. The study therefore concluded that if there is high brand loyalty then brand switching will be less and cellular organizations have to be careful regarding it that the needs, wants and the expectations of the customers have to be analyzed and then formulate the appropriate strategies to focus.

Salisu and Ibrahim (2014) examined the separate effects of reform and the reformed telecommunications on the various measures of economic performance using Nigeria's data for the period 1984 to 2011. The study made used of trend analysis and the Modified EngleGranger co-integration test that allows for structural break in measuring long-run relationships. A step dummy variable was used to measure the effects of the reform on the various indicators of economic performance, while a slope dummy was used to measure the effects of the reformed telecommunications sector on economic performance. The findings of the study revealed that the reform and the reformed telecommunications have significant effects on economic performance. Their effects on growth were found to be statistically significant both in the short-run and in the long-run. Although, the effects on unemployment and Poverty are found to be significant only in the long-run. The study also found that the effects of the reform was very important. Brown (1974) investigated instant coffee purchasers and tracked their brand loyalty/switching behaviour shortly after some changes in advertising and promotional strategies were made by two major manufacturers. His major findings was that promotions yield fast responses in sales, but these promotions do not produce new long term buyers. Oghojafor et al. (2014) examined the marketing activities that influence customer satisfaction and the factors that determine customer loyalty in the industry. The study made used of cross-sectional survey research design and a purposive sampling technique. The population of the study comprised all subscribers of telecommunication services in Lagos State, Nigeria and the study used five constructs of marketing variables such as product, price, distribution, promotion and customer service and all were tested. A sample size of one thousand (1000) respondents were selected and the data obtained were structured into close-ended questions. The findings showed that product (core service), promotion and distribution have a higher impact on the level of customer satisfaction. The study further found that, apart from customer satisfaction, trust is a major determinant of customer loyalty in the telecoms market.

Uppu et al. (2016) examined brand-switching attitude, information sources for brand switching, factors prompting brand switching and brand switching behavior. The study made used of primary sources of data and a survey research design. The study used three user groups and these groups were identified based on their occupation such as Businesses, Employees and Professionals and the sample units are distributed equally among the three (3) income groups between male and female in each consumer group. The study employed stratified sampling technique. The sample size comprised three hundred and sixty (360) respondents and each customer group that is business people were 360; professionals 360 and employees 360. To have a nationwide representation of the sample, the study used six metropolitan cities in India namely Delhi, Mumbai, Calcutta, Chennai, Bangalore and Hyderabad. The sample was divided equally amongst all metro cities. The sample size is one thousand and eighty $(1,080)$ respondents. The data was collected during August to November 2015 . The findings of the study revealed that fifty five point sixty five percent (55.65\%) of the respondents have the intention to switch brands, and forty three point thirty three percent $(43.33 \%)$ of the respondents have changed their service providers during the last year; while fifty six point sixty percent $(56.67 \%)$ still continued with the same service provider. Advertisements were the chief source of information for the consumers of mobile services to identify the better service providers and to satisfy their desire for brand switching and the impact of information sources like social networking, retailer/sales persons are insignificant. Price, quality, product features and applications, competitive offer, after sales services and change in income level influenced brand-switching behavior significantly in the case of mobile services. Quality services were the most influencing factor, followed by price and product features and applications influencing brand-switching behavior. The consumer prefers to switch brands when competitors offer additional service features or when they found that there were no product improvements in the existing brand for a long time. It was noted that seventy seven point ten percent (77.10\%) of the respondents do not communicate the dissatisfaction of the service to the service provider.

Shehzad and Moosavi (2013) investigated the factors that influence brand loyalty of mobile phone on the Y generation in Sweden. The findings revealed that the majority of $Y$ generation show loyalty to their mobile where the quality of the brand, brand image, brand experience and customer satisfaction are factors influencing loyalty. Uadiale and Fagbemi (2012) examined the impact of corporate social responsibility activities on financial performance in developing economies, considering employee relations, company performance and environmental management system as independent variables, while the dependent variables were measured with Return on Equity and Return on Assets in Nigerian companies. The study used a sample of forty (40) audited financial statements of quoted companies in Nigeria in the year 2007. Using content analysis for corporate social responsibility, regression analysis model was used and the result revealed that, corporate social responsibility has a positive and significant association with the financial performance measures. Ogungbade (2021) ascertained corporate social responsibility and financial performance of deposit money banks: A new evidence from Nigeria and provided new evidence on the relationship between corporate social responsibility (CSR) and performance from Nigeria by disaggregating CSR into Community Development, Education and Health, and finding their effect on performance proxy by Return on Assets. The data were obtained from the audited annual reports of twelve (12) Deposit Money Banks listed on Nigeria Stock Exchange for the period of ten years (2009-2018). The findings of the study revealed that CSR cost on Community Developments has a positive and significant effect on 
financial performance. Also, the findings showed that CSR cost on Education has a positive and insignificant effect on financial performance, the findings further revealed that CSR cost on Health has a negative and insignificant effect on financial performance.

Baohong et al. (2003) examined whether brand-switching elasticity's derived from logit choice models are overestimated as a result of rational user adjustment of purchase timing to concur with promotion agendas and whether a dynamic structural model can address this bias. They used simulated data and demonstrated that if the structural model is correct, brand-switching elasticity's are overestimated by stand-alone logit models, while a nested logit model improves the estimates, but not completely. They also estimated the models on real data and the findings revealed that the structural model fits better and produced sensible coefficient estimates. Furthermore, they observed the same pattern in switching elasticity's as they do in the simulation. They predicted sales to be fifty percent (50\%) increase in promotion frequency. The reduced-form models predict higher sales levels than the dynamic structural model. They agree that reduced-form model estimates of brand-switching elasticity's can be overstated and that a dynamic structural model is the best for addressing the problem. Reduced-form models that include incidence can partially, though not completely, address the issue. They discussed the implications for investigators and managers, measuring the impact of promotions on brand switching when users' forward looking logit choice models have proved an invaluable tool for studying user decision processes. Keffas and Olulu-Briggs (2011) examined the financial performance of corporate social responsibility and non-corporate social responsibility banks and made used of financial ratios and frontier efficiency analysis. They got accounting information for banks in Japan, US and UK quoted on the FTSE4 Good global index from Bank scope database. They used thirty-eight (38) financial and economic ratios such as asset quality, capital, operations and liquidity variables that captured the key scope of financial performance. Furthermore, they used Data Envelopment Analysis of a non-parametric linear programming technique to create a piecewise linear frontier that helped to determine the efficiency levels for both a general and separate frontier analyses. The findings showed a positive association between corporate social responsibility and financial performance. More so, banks that incorporate corporate social responsibility have good asset quality; capital adequacy, and are more efficient in managing their asset portfolios and capital. The study also found that geographical location regulates the association between corporate social responsibility and financial performance during economic contraction, such that; the relationship differs across the businesses and transactional banking models. The findings were to some extent reliable with prior investigation on the corporate social responsibility-financial performance studies.

Wissink (2012) examined the association between corporate social responsibility and corporate financial performance. The study made of the world two thousand five hundred (2500) largest companies. The study used secondary sources of data based on general and industry specific sustainability criteria by means of self-report questionnaire, media- and stakeholder analysis from the company's websites and annual reports. The combined results showed that the association between corporate social responsibility and corporate financial performance is at least neutral and perhaps slightly positive. The result was put to test once more, but only after trying to come to a more general conceptualization and operationalization of the variables, based on the inclusion of Dow Jones Sustainability Index and Corporate financial performance was operationalized by means of three different accounting variables: ROA, ROE and ROS. Amole et al. (2012) examined corporate social responsibility and profitability of Nigerian banks based on causal relationship, the study used First Bank Nigeria Plc as a study for the period of ten years (2001-2010). The independent variable is the corporate social responsibility expenditure for the period under study, while the dependent variable is profit after tax. The data was analyzed using correlation and regression methods, and the results revealed a significant and positive relationship of corporate social responsibility on profit after tax. Idamoyibo (2017) examined brand switching in communication networks amongst students of the Delta State University, Abraka. The study made used of primary data and the population comprised seventy eight thousand nine hundred and twelve $(78,912)$ regular registered undergraduate students. The sample size of the study consists of three hundred and ninety eight (398) respondents and these was drawn using Taro Yamen's formula at five percent (5\%) error and ninety five (95\%) level of significance. A conclusive (cross sectional descriptive) research design and judgmental sampling technique of non-probability sample was adopted for this study. The study made used of structured questionnaire, oral interview and direct observation as instrument for data collection. Four (4) hypotheses were formulated and tested using chi-square $\left(\mathrm{X}^{2}\right)$. The findings revealed that brand switching behavior of students, with regards to communication networks, has been influenced by advertising, price, and quality service. Brand image, as revealed in this study, does not have direct influence on students for brand switching significantly. The study concluded that students' behavior towards brand switching of communication networks is regulated by some factors such as trust, perceived expectation, cost of call rate, network reception, speed of online access, availability of network coverage, network bonus and packaging which play very important roles in the process of choice making.

Jothi et al. (2011) examined the effectiveness of brand communication strategy followed in social networking sites which are largely accessed by Indian users. The study employed survey research design and content analysis to find the effectiveness of communication strategy in developing brand in social networking sites. The findings showed that the respondents answer more to the interactive marketing than the traditional ads trailed in internet advertising. A number of individuals were communicated through social networking sites, seventy percent $(70 \%)$ of the respondents has impact through ads in social networking sites, and some of the respondent access the ads such as games, quiz, events and others. The users patronize the brand through advertisement and they react to new forms of advertising which they have interest on. The social networking sites becomes the primary showground for highly targeted marketing and advertising of products. The social networking sites present unparalleled opportunity to build brands. The users of face book and Orkut are of same age range. In twitter, users do not show much interest because it's just like a micro-blogging site and the interaction is more in the show of banners advertisements in face book and Orkut. The whole networking sites have their personal space in their web pages for ads promotion, and also the communication strategy and user interaction are exceptional among each site. The face book promote and permits user interaction, and Twitter often feed posts regarding the brand, while Orkut promote through click ads and promotional brand pages. Face book follows a default backdrop and text while twitter and Orkut can be customized. However, accessibility is more in face book than other ads. Twitter display importance only for text and users expect brand communication than brand marketing in the social networking sites. Hodgson (2004) illustrated and ascertained the associations between marketing communications expenditure on two data sets representing firms in listed and non-listed settings. The study adopted time series and employed Pooled time series/cross section (panel data) analysis to analyze the data. The findings showed that marketing outlay has a significant role in the creation of shareholder value, the stock and flow effects are both existing. The study concluded that in the retailing industry, higher levels of advertising outlay have a negative impact on stock prices and the indirect effects display that transaction marketing is perhaps more effective. More so, the findings encourage marketers to further examine nonlinear associations between marketing, finance and accounting variables and the nonlinear models have the potential to expand researchers thought of marketing phenomena and the elusive nature of the associations.

Olumoko et al. (2012) determine the role of personal selling in enhancing clients' satisfaction in the Nigerian insurance market and to display the effectiveness of personal selling as a promotional tool for insurance services. The study employed primary sources of data and made used of descriptive cross-sectional survey research design. The study used one hundred and ten (110) respondents that was randomly selected. The data were analyze using descriptive and inferential statistical instruments, and independent T-test was used to test the hypotheses. The findings of the study shown that personal selling strategy is the most useful marketing communication tool that should be 
encompassed by Nigerian firms. It may also be used to improve the image of the industry. The implication of the result is that insurance salespersons contribute greatly to the improvement of the image of insurance services in Nigeria.

\section{Methods}

The research design adopted ex-post facto research design. The study made use of secondary sources of data that was obtained from the annual reports of the four telecommunication firms in Nigeria for the period 2008-2019. The population of the study consists of the four (4) known telecommunication providers in Nigeria, these are MTN, GLO, 9Mobile, and Airtel. The study made use of all four (4) telecommunication providers in Nigeria as sample for the study and it used the annual reports of these four (4) telecommunication providers in Nigeria for data analysis. The study employed ordinary least square (OLS) technique and panel regression analysis with application of econometrics software package E-view version 10 to test the hypotheses. The choice of panel regression against other analytical techniques is based on the number of companies with similar data parameters and observations.

\subsection{Model specification}

This is expressed in its functional form as follows:

$$
\begin{aligned}
& \mathrm{ROA}_{\text {telecom }}=\mathrm{f}(\mathrm{AC}) \\
& \mathrm{ROE}_{\text {telecom }}=\mathrm{f}(\mathrm{SC}) \\
& \mathrm{PRM}_{\text {telecom }}=\mathrm{f}(\mathrm{CE})
\end{aligned}
$$

Where:

$\mathrm{ROA}=$ Returns on assets of the telecom firms.

$\mathrm{ROE}=$ Returns on equity of the telecom firms.

$\mathrm{PRM}=$ Profit Margin of the telecom firms

$\mathrm{AC}=$ Advertising costs

$\mathrm{SC}=$ Sales costs

$\mathrm{CE}=$ Celebrity Endorsement

The above functional equation is further stated in econometric form as presented below:

$$
\begin{aligned}
& \mathrm{ROA}_{t}=\beta_{0 t}-\beta_{1} A_{t}+U i \\
& \operatorname{ROE}_{t}=\beta_{0 t}-\beta_{1} \mathrm{SC}_{\mathrm{t}}+\mathrm{Ui} \\
& \mathrm{PRM}_{t}=\beta_{0 t}-\beta_{1} \mathrm{CE}_{t}+\mathrm{Ui}
\end{aligned}
$$

Where:

$\mathrm{U}_{\mathrm{i}}=$ Error Term

$\beta_{0}-\beta_{1}=$ the Parameters

A prior Expectation $=\beta_{2}<0$

\subsection{Data presentation}

For the models I, II and III, the analyses below were performed to capture the fixed, random effects and pooled estimates of the models. The descriptive analysis shows that ROA is normally distributed in model I, ROE in model II and PRM in model III. More so, analysis on the Panel Augmented Dickey-Fuller tests, Granger Causality Tests and the Co integration tests were performed and presented below.

Table 1: Descriptive Statistics Results Model I

\begin{tabular}{llc}
\hline & ROA & AC \\
\hline Mean & 212450.2 & 88.45442 \\
Median & 821.8400 & 17.90289 \\
Maximum & 33014444 & 108.7999 \\
Minimum & 4.050000 & 0.022441 \\
Std. Dev. & 2479574. & 18.77744 \\
Skewness & 0.217982 & 1.494717 \\
Kurtosis & 0.257548 & 4.240449 \\
Jarque-Bera & 11.20744 & 458.4448 \\
Probability & 0.493222 & 0.003211 \\
Sum & 1.714308 & 10428.94 \\
Sum Sq. Dev. & 3.584315 & 175947.7 \\
Observations & 88 & 88 \\
\hline Source: Author's comp
\end{tabular}

Source: Author's computation using E-view 10.0. 
Table 2: Descriptive Statistics Results Model II

\begin{tabular}{lll}
\hline & ROE & SC \\
\hline Mean & 212450.2 & 7.429889 \\
Median & 821.8400 & 7.432122 \\
Maximum & 3308444 & 9.43423 \\
Minimum & 4.050000 & 5.173415 \\
Std. Dev. & 2479574. & 0.970704 \\
Skewness & 0.217982 & 0.151949 \\
Kurtosis & 0.257548 & 2.112430 \\
Jarque-Bera & 11.20744 & 12.94478 \\
Probability & 0.493222 & 0.001544 \\
Sum & 1.714308 & 3714.945 \\
Sum Sq. Dev. & 3.584315 & 470.2524 \\
Observations & 88 & 88 \\
\hline Source: Author's comp
\end{tabular}

Source: Author's computation using E-view 10.0.

Table 3: Descriptive Statistics Results Model Iii

\begin{tabular}{lcc}
\hline & PRM & CE \\
\hline Mean & 212450.2 & 0.380944 \\
Median & 821.8400 & 0.180000 \\
Maximum & 33014444 & 4.510000 \\
Minimum & 4.050000 & -0.530000 \\
Std. Dev. & 2479574. & 0.543172 \\
Skewness & 0.217982 & 5.015188 \\
Kurtosis & 0.257548 & 45.98212 \\
Jarque-Bera & 11.20744 & 40584.82 \\
Probability & 0.493222 & 0.007819 \\
Sum & 1.714308 & 190.4719 \\
Sum Sq. Dev. & 3.584315 & 147.2230 \\
Observations & 88 & 88 \\
\hline Source: Auth's & \\
\end{tabular}

Source: Author's computation using E-view 10.0.

\subsection{Panel regression}

The researcher, using the panel regression analysis, examined the model based on the pooled, fixed effects and random effects. The choice of best fit among the variables is made possible using the Hausman test.

\subsection{Panel regression tests}

Table 4: Model I: Comparism of Pooled, Fixed and Random Effects Estimates

\begin{tabular}{|c|c|c|c|c|c|c|}
\hline & \multicolumn{2}{|c|}{ Pooled Estimates } & \multicolumn{2}{|c|}{ Random Effects } & \multicolumn{2}{|c|}{ Panel OLS (Fixed effects) } \\
\hline Variables & Coeff & Prob. & Coeff. & Prob. & Coeff. & Prob. \\
\hline $\mathrm{C}$ & & & -17.67797 & 0.9158 & 56.06374 & 0.4058 \\
\hline AC & -14338.41 & 0.0000 & 31.47173 & 0.4003 & -4.117155 & 0.0000 \\
\hline $\mathrm{R}^{2}$ & 0.049224 & & 0.444745 & & 0.515223 & \\
\hline F-Test & & & 0.557971 & & 4.478914 & \\
\hline DW & 0.453345 & & 0.870998 & & 2.945154 & \\
\hline
\end{tabular}

Source: Author's computation, E-view 10.0.

Table 5: Model II: Comparism of Pooled, Fixed and Random Effects Estimates

\begin{tabular}{llllll}
\hline & Pooled Estimates & & Random Effects & & Panel OLS (Fixed effects) \\
\hline Variables & Coeff & Prob. & Coeff. & Prob. & Coeff. \\
C & 540437.4 & 0.7915 & -0.455393 & 0.9008 & 56.06374 \\
SC & 34802.55 & 0.8995 & 55.94335 & 0.4790 & -6.727155 \\
R $^{2}$ & 0.715117 & & 0.444745 & & 0.715223 \\
F-Test & & & 0.557971 & 4.478914 \\
DW & 0.945154 & & 0.870998 & & 0.0000 \\
\hline
\end{tabular}

Source: Author's computation, Eviews 10.0.

Table 6: Model III: Comparism of Pooled, Fixed and Random Effects Estimates

\begin{tabular}{llllll}
\hline & Pooled Estimates & & Random Effects & \multicolumn{2}{c}{ Panel OLS (Fixed effects) } \\
\hline Variables & Coeff & Prob. & Coeff. & Prob. & Coeff. \\
C & & 0.7915 & -0.455393 & 0.1888 & 54.04374 \\
CE & -439359.2 & 0.8995 & -2.443108 & 0.4004 & -4.311577 \\
R $^{2}$ & 0.049224 & & 0.512745 & 0.9815 & 0.0342 \\
F-Test & & & 0.112331 & 4.478914 \\
DW & 0.453345 & & 0.870998 & & 2.945154 \\
\hline
\end{tabular}

Source: Author's computation, E-view 10.0. 
Regression assumption tests

Tests of multicollinearity

Variance Inflation Factors

Model I

Date: 04/28/20 Time: 02:09
Sample: 188

Included observations: 88

$\begin{array}{llll}\text { Variable } & \begin{array}{l}\text { Coefficient } \\ \text { Variance }\end{array} & \text { Uncentered } & \text { Centered } \\ \text { VIF }\end{array}$

Source: Author's Computation, E-view 10.0

Model II

Variance Inflation Factors

Date: 04/28/20 Time: 02:09

Sample: 188

Included observations: 88

$\begin{array}{llll} & \begin{array}{l}\text { Coefficient } \\ \text { Variance }\end{array} & \text { Uncentered } & \text { Centered } \\ \text { VIF }\end{array}$

Source: Author's Computation, E-view 10.0

Model III

Variance Inflation Factors

Date: 04/28/20 Time: 02:09

Sample: 188

Included observations: 88

\begin{tabular}{|c|c|c|c|}
\hline Variable & $\begin{array}{l}\text { Coefficient } \\
\text { Variance }\end{array}$ & $\begin{array}{l}\text { Uncentered } \\
\text { VIF }\end{array}$ & $\begin{array}{l}\text { Centered } \\
\text { VIF }\end{array}$ \\
\hline $\mathrm{C}$ & 8.883233 & 78.74332 & NA \\
\hline $\mathrm{CE}$ & 4.930012 & 44.87322 & 1.834402 \\
\hline
\end{tabular}

As shown in the tables above, none of the variables has a variance inflation factors (VIFs) value exceeding 10 for the centred VIFs and hence all the variables are upheld in the regression models.

Serial autocorrelation tests

Model I

\begin{tabular}{|c|c|c|c|}
\hline Breusch-Godfre & & & \\
\hline F-statistic & 122.4422 & Prob. $F(2,151)$ & 0.1141 \\
\hline Obs*R-squared & 125.8182 & Prob. Chi-Square (2) & 0.1322 \\
\hline
\end{tabular}

Source: Author's Computation, E-view 10.0.

Model II

\begin{tabular}{lll}
\hline Breusch-Godfrey Serial Correlation LM Test: & & \\
\hline F-statistic & 121.8422 & Prob. F(2,151) \\
Obs*R-squared & 15.12142 & Prob. Chi-Square(2)
\end{tabular}

Source: Author's Computation, E-view 10.0.

Model III

\begin{tabular}{lll}
\hline Breusch-Godfrey Serial Correlation LM Test: & & \\
\hline F-statistic & 21.18422 & Prob. F(2,151) \\
Obs*R-squared & 21.55182 & Prob. Chi-Square(2) \\
\hline Source: Auth's Computation 1 E-view 10.0.
\end{tabular}

Source: Author's Computation, E-view 10.0.

The analysis above showed that the serial correlations of the models are above 0.05 . We therefore reject the null hypotheses that there is no serial autocorrelation in the model. 
Ramsey reset tests

Model I

\begin{tabular}{llcl}
\hline Ramsey RESET Test & & & \\
\hline Equation: REGRESSION_1 & & & \\
Specification: ROA C AC & & df & Probability \\
Omitted Variables: Squares of fitted values & Value & 86 & 0.0005 \\
& 12.21007 & $(1,86)$ & 0.0000 \\
t-statistic & 11.50774 & 1 & 0.0111 \\
F-statistic & 33.17794 & & 1 \\
Likelihood ratio & & & \\
\hline
\end{tabular}

Source: Author's Computation, E-view 10.0.

Mode II

\begin{tabular}{llcc}
\hline Ramsey RESET Test & & & \\
\hline Equation: REGRESSION_1 & & & \\
Specification: ROE C SC & & df & Probability \\
Omitted Variables: Squares of fitted values & Value & 86 & 0.0031 \\
t-statistic & 32.29217 & $(1,86)$ & 0.0002 \\
F-statistic & 41.15994 & 1 & 0.0011 \\
Likelihood ratio & 33.17794 & & 1 \\
\hline
\end{tabular}

Source: Author's Computation, E-view 10.0.

Model III

Ramsey RESET Test

Equation: REGRESSION_1

Specification: PRM C CE

Omitted Variables: Squares of fitted values

t-statistic $\quad$ Value

F-statistic $\quad 151.5994$

Likelihood ratio 121.7794

Source: Author's computation, E-view 10.0

To check for the model misspecifications, the Ramsey RESET test was used. The performance of the Ramsey RESET test on the model showed low probability values that are lesser than 0.05 . This means that there was no significant evidence of misspecification in the model used.

Hausman tests

Model I

\begin{tabular}{lll}
\hline Correlated Random Effects - Hausman Test & & \\
\hline Equation: Untitled & & \\
Test cross-section random effects & Chi-Sq. Statistic & Chi-Sq. d.f. \\
Test Summary & 1.719421 & 4 \\
Cross-section random & & Prob. \\
\hline
\end{tabular}

Source: Author's Computation, E-view 10.0.

Model II

\section{Correlated Random Effects - Hausman Test}

Equation: Untitled

Test cross-section random effects

Test Summary

Cross-section random

1.71942

df

140

$(1,140)$

1

0.0042

0.0051

Source: Author's Computation, E-view 10.0.

Correlated Random Effects - Hausman Test

Equation: Untitled

Test cross-section random effects

Test Summary

Cross-section random

5.421801

Chi-Sq. d.f

Prob.

Source: Author's Computation, E-view 10.0.

Chi-Sq. Statistic

4.615401
Chi-Sq. d.f.
Prob.

0.0003

Hausman test helps to make a choice between fixed and random effects model fits. The null hypothesis states that the random effect is a better model fit while the alternative states that the fixed is a better model fit. The analyses above showed that the fixed effect models of the panel data analysis are better models than the random effect models. 
Unit root property test

Augmented-Dickey fuller tests results

\begin{tabular}{lccc}
\hline Coefficients & ADF Values & Probability & Comments \\
\hline ROA & 281.471 & 0.0000 & $1(0)$ \\
ROE & 51.9311 & 0.0003 & $1(0)$ \\
PRM & 236.307 & 0.0000 & $1(0)$ \\
SC & 236.307 & 0.0000 & $1(0)$ \\
AC & 77.2551 & 0.0000 & $1(0)$ \\
CE & 211.411 & 0.0000 & $1(0)$ \\
\hline
\end{tabular}

Source: Authors Computation E-view 10.0.

The table above showed the results of the ADF Panel Unit Root Tests of all the variables. The results are found to be integrated of the same order. At first difference, the p-values are found to be less than 5\% which is the level of significance. All the variables are shown to be stationary.

Co-integration analysis test

Co-integration tests results

Model I

Pedroni Residual Cointegration Test

Series: ROA AC

Date: 04/28/20 Time: 11:24

Sample: 20082019

Included observations: 88

Cross-sections included: 4 (1 dropped)

Null Hypothesis: 1 cointegrationeqn(s)

Trend assumption: No deterministic trend

User-specified lag length: 1

Newey-West automatic bandwidth selection and Bartlett kernel

Alternative hypothesis: common AR coefs. (within-dimension)

\begin{tabular}{|c|c|c|c|c|}
\hline & Statistic & Prob. & $\begin{array}{l}\text { Weighted } \\
\text { Statistic }\end{array}$ & Prob. \\
\hline Panel v-Statistic & -0.544540 & 0.0070 & -0.524050 & 0.7014 \\
\hline Panel rho-Statistic & -0.332485 & 0.3444 & 0.174204 & 0.5711 \\
\hline Panel PP-Statistic & -1.348044 & 0.0854 & -1.144540 & 0.1242 \\
\hline Panel ADF-Statistic & -0.034474 & 0.4853 & -0.401442 & 0.1134 \\
\hline
\end{tabular}

Source: Author's Computation, E-view 10.0.

Pedroni Residual Cointegration Test

Series: ROE SC

Date: 04/28/20 Time: 11:24

Sample: 20082019

Included observations: 88

Cross-sections included: 4 (1 dropped)

Null Hypothesis: 1 cointegrationeqn(s)

Trend assumption: No deterministic trend

User-specified lag length: 1

Newey-West automatic bandwidth selection and Bartlett kernel

Alternative hypothesis: common AR coefs. (within-dimension)

\begin{tabular}{|c|c|c|c|c|}
\hline & Statistic & Prob. & $\begin{array}{l}\text { Weighted } \\
\text { Statistic }\end{array}$ & Prob. \\
\hline Panel v-Statistic & -0.544540 & 0.0070 & -0.524050 & 0.7014 \\
\hline Panel rho-Statistic & -0.332485 & 0.3444 & 0.174204 & 0.5711 \\
\hline Panel PP-Statistic & -1.348044 & 0.0854 & -1.84540 & 0.1242 \\
\hline Panel ADF-Statistic & -0.034474 & 0.4853 & -0.40842 & 0.1134 \\
\hline
\end{tabular}

Source: Author's Computation, E-view 10.0.

Pedroni Residual Cointegration Test

Series: PRM AC

Date: 04/28/20 Time: 11:24

Sample: 20082019

Included observations: 88

Cross-sections included: 4 (1 dropped)

Null Hypothesis: 1 cointegrationeqn(s)

Trend assumption: No deterministic trend

User-specified lag length: 1

Newey-West automatic bandwidth selection and Bartlett kernel

Alternative hypothesis: common AR coefs. (within-dimension)

\begin{tabular}{llcc} 
& & & Weighted \\
& Statistic & Prob. & Statistic \\
Panel v-Statistic & -0.544540 & 0.0070 & -0.524050 \\
Panel rho-Statistic & -0.332485 & 0.3444 & 0.174204 \\
Panel PP-Statistic & -1.348044 & 0.0854 & 0.7014 \\
Panel ADF-Statistic & -0.034474 & 0.4853 & 0.5711 \\
\hline
\end{tabular}

Source: Author's Computation, E-view 10.0. 
Co-integration revealed whether or not the variables have a long-term relationship. As the table above showed in both models using the panel v-Statistic results, the co-integration analyses met the required criterion for the acceptability of the result.

Serial autocorrelation tests

Serial autocorrelation is conducted alongside the OLS analysis. It showed if there is a serial relationship between a variable in time ( $\mathrm{t}$ ) and the same variable in time ( $\left.\mathrm{t}_{-1}\right)$. This usually leads to unreliable results of the OLS. The results showed that there is no serial correlation among the variables.

\begin{tabular}{|c|c|c|c|}
\hline \multicolumn{4}{|c|}{ Model I } \\
\hline Breusch-Godfrey & & & \\
\hline F-statistic & 331.3422 & Prob. $\mathrm{F}(2,151)$ & 0.3131 \\
\hline Obs*R-squared & 115.8902 & Prob. Chi-Square(2) & 0.1450 \\
\hline
\end{tabular}

Source: Author's Computation, E-view 10.0.

Model II

\begin{tabular}{lrll}
\hline Breusch-Godfrey Serial Correlation LM Test: & & \\
\hline F-statistic & 41.18422 & Prob. F(2,151) & 0.5431 \\
Obs*R-squared & 55.54842 & Prob. Chi-Square(2) & 0.1330 \\
\hline
\end{tabular}

Source: Author's Computation, E-view 10.0.

\begin{tabular}{llll} 
& \multicolumn{2}{l}{ Model III } \\
\hline Breusch-Godfrey Serial Correlation LM Test: & & \\
\hline F-statistic & 31.48422 & Prob. F(2,151) & 0.2431 \\
Obs*R-squared & 55.81482 & Prob. Chi-Square(2) & 0.0130 \\
\hline
\end{tabular}

Source: Author's Computation, E-view 10.0

Heteroskedasticity tests

This tests if the variances of the models are the same over time. The rule of thumb is the use of the prob. being more than 0.05 . Heteroscedasticity is lack of constant error variance (Gujarati, 2003). This is a problem that makes the standard errors biased, leading to bias or invalid test statistics and confidence intervals (Wooldridge, 2010).

Heteroskedasticity Tests Results

\begin{tabular}{llll}
\multicolumn{3}{c}{ Model I } \\
\hline Heteroskedasticity Test: Breusch-Pagan-Godfrey & & \\
\hline F-statistic & 2.448287 & Prob. F(8,151) & 0.1221 \\
Obs*R-squared & 14.01244 & Prob. Chi-Square(8) & 0.0010 \\
Scaled explained SS & 1142.520 & Prob. Chi-Square(8) & 0.0000 \\
\hline Source: Author's Col
\end{tabular}

Source: Author's Computation, E-view 10.0.

Model II

\begin{tabular}{llll}
\hline Heteroskedasticity Test: Breusch-Pagan-Godfrey & & & \\
\hline F-statistic & 2.448287 & Prob. F $(8,151)$ & 0.1009 \\
Obs*R-squared & 24.01244 & Prob. Chi-Square(8) & 0.0010 \\
SCaled explained SS & 1042.520 & Prob. Chi-Square $(8)$ & 0.0000 \\
\hline
\end{tabular}

Source: Author's Computation, E-view 10.0.

Model III

\begin{tabular}{llll}
\hline Heteroskedasticity Test: Breusch-Pagan-Godfrey & & & \\
\hline F-statistic & 3.322137 & Prob. F(8,151) & 0.1187 \\
Obs*R-squared & 24.00044 & Prob. Chi-Square $(8)$ & 0.0000 \\
Scaled explained SS & 4442.520 & Prob. Chi-Square $(8)$ & 0.0000 \\
\hline
\end{tabular}

Source: Author's Computation, E-view 10.0.

Granger Causality Tests

Model I

\begin{tabular}{lc}
\hline Pairwise Granger Causality Tests & \\
\hline Date: 04/28/20 Time: 02:18 & \\
Sample: 20082019 & Obs \\
Lags: 2 & F-Statistic \\
Null Hypothesis: & 4.18819 \\
AC does not Granger Cause ROA & Prob. \\
ROA does not Granger Cause AC & 0.0444 \\
\hline
\end{tabular}

Source: Author's Computation, E-view 10.0.

Model II

Pairwise Granger Causality Tests

Date: 04/28/20 Time: 02:4

Sample: 20082019

Lags: 2

Null Hypothesis:

SC does not Granger Cause ROE

ROE does not Granger Cause SC

Source: Author's Computation, E-view 10.0. 
Model III

\begin{tabular}{lcc}
\hline Pairwise Granger Causality Tests & \\
\hline Date: 04/28/20 Time: 02:18 & \\
Sample: 20082019 & Obs & F-Statistic \\
Lags: 2 & 84 & 4.10280 \\
Null Hypothesis: & 0.24823 \\
CE does not Granger Cause PRM & 0.0023 \\
PRM does not Granger Cause CE & 0.7448 \\
\hline
\end{tabular}

Source: Author's Computation, E-view 10.0.

The granger tests test for the direction of cause between two variables. The results in the models showed that there are unidirectional causalities between the dependent and the independent variables.

\section{Results}

Having chosen the Fixed Effect models as a better fit model, the analyses were based on the fixed effect model.

In model $\mathrm{I}$, the result showed that $\mathrm{R}^{2}=52 \%$ of the changes in the dependent variable are explained by the changes in the independent variables. F-test showed that the overall model is statistically significant at $5 \%$ level, while the DW showed there is no presence of serial autocorrelation.

In model II, the coefficient of determination is $72 \%$; the f-test is 4.5 , while the DW is 2.9 . The model is generally a good fit.

In model III, the goodness-of-fit is also good at $52 \%$; f-test showed that the model is generally significant, while the DW showed the absence of serial autocorrelation of the first order.

$\mathrm{H}_{1}$ : the result showed that $\mathrm{AC}$ has negative and significant impact on the ROA over the period. As the AC increased by a unit percentage, the ROA decreased by -4.1 units and vice versa. Again, the result showed that AC is statistically significant at $5 \%$ level of significance. We therefore accept the alternative hypothesis, reject the null and conclude that $\mathrm{AC}$ has positive and significant impact on ROA over the period under study.

$\mathrm{H}_{2}$ : the result showed that $\mathrm{SC}$ also has negative and significant impact on the ROE over the period. As the SC increased by a unit, the ROE decreased by -6.7 units and vice versa. Again, the result showed that SC is statistically significant at $5 \%$ level of significance. We therefore accept the alternative hypothesis, reject the null and conclude that SC has positive and significant impact on ROE over the period under study.

$\mathrm{H}_{3}$ : Finally, the result showed that CE has positive and significant impact on the PRM over the period. As the CE increased by a unit, the PRM increased by -4.3 units and vice versa. Further, the result showed that CE is statistically significant at $5 \%$ level of significance, using the $\mathrm{t}$-value. We therefore accept the alternative hypothesis, reject the null and conclude that CE has positive and significant impact on PRM over the period.

\section{Discussions}

The results of the analysis have shown the different behavioral patterns of brand promotion cost outlay on the financial performances of the telecommunications industries in Nigeria over the period of time used for the study.

As shown above, the result shown that advertising cost has a positive but significant impact on return on assets. As the firms AC decreased, the ROA increased and vice versa. This disagreed with the findings of Doob et al. (1969) who found that advertising costs have a negative and significant relationship when they conducted a study on advertising cost and consumer goods performance of some selected firms. The finding of this study agreed with that of Pan et al. (2014) whose finding showed that corporate social responsibility has important effects on Return on Asset, which specifies that corporate social responsibility subjects may benefit a company in terms of cost reductions, thus it would lead to a profit increase.

Equally, the analysis showed that the sales cost of the firms has a positive and significant impact on return on equity. Evidently, this showed that as the firms commit more money into the sales of their products/services, their returns on equities decreased and vice versa. This finding disagreed with the findings of Baohong et al. (2003). They found that there is a negative relationship between SC and ROE of the respective parameters they used in their study. However, the finding of this study agreed with that of Brown (1974) who conducted a study on coffee purchasers and found that sales cost actually adds to the ROE of the firms used. The finding disagreed with the findings of Ogungbade (2021) who studied corporate social responsibility (CSR) and performance of deposit money banks: A new evidence from Nigeria and found that CSR cost on Health has a negative and significant effect on financial performance.

Finally, the study was able to ascertained Celebrity endorsement cost of firms on profit margin and found that CE has a positive and significant impact on PRM over the period. This could explain the reason telecommunication firms in Nigeria have been favoring the use of celebrities over the years. The finding of this study agreed with the findings of Brown (1974); and Baohong et al. (2003) whose respective works have pointed out that the use of a god-like figure to market goods increased the firms' value and consequently, their profits. The finding of this study also agreed with the findings of Adebayo et al. (2012) which have proven that performance and reporting of social responsibility bring improvement in the reputation, sales and profit levels of firms working in Nigeria. Furthermore, the finding of this study agreed with the finding of Ogungbade (2021) who studied corporate social responsibility (CSR) and performance of deposit money banks: A new evidence from Nigeria and found that CSR cost on Community Developments has a positive and significant effect on financial performance, also CSR cost on education has a positive but insignificant effect on financial performance.

\section{Conclusion}

The study revealed that there is a negative and significant impact on some elements of brand promotion on the return on assets and equity of the firms as shown in the analysis. The study however, revealed that there is a positive and significant impact of advertising cost on return on asset of financial performance, this is based on 5\% level of significance of the result. While sales cost also has a positive and significant impact on return on equity of financial performance, this is based on 5\% level of significance of the result. The study also showed that there is a positive and significant impact of celebrity endorsement cost on profit margin of financial performance, and this 
could explain the reason why telecommunication industries in Nigeria have been favoring the use of celebrities in promoting their products. The study therefore, concluded that there is a positive and significant impact of brand promotion cost outlay on financial performance of telecommunication industries in Nigeria. It further concluded from the analysis that the panel ADF was stationary at first differencing for all the variables. The result of the co-integration test showed that there is a long term impact of the dependent and the independent variables, while the result from the Hausman test revealed that the fixed model is a better fit for the testing of the hypotheses in the study.

\section{References}

[1] Abdullahj, S. R., Oni, I., Ahmeb, M. D., Shakur, F. I (2015). Effects of standard costing on the profitability of telecommunication companies (study of MTN Nigeria). Arabian Journal of Business and Management Review (OMAN Chapter), 5(1), 1-8.

[2] Achumba, I. C. (2000). Strategic marketing management in the $21^{\text {st }}$ century. Charotte USA: Mac-Williams and Capital Publishers Inc.

[3] Adebayo, O., Olurin, O. T., \& Akuyemi, M. E. (2012). Corporate social responsibility reporting and financial performance of money deposit banks in Nigeria. Prime Journal of Business Administration and Management (BAM), 2(11), 758- 769.

[4] Adeleke, A., Aminu, S. (2012). The determinants of customer loyalty in Nigeria's GSM market. International Journal of Business and Social Science, 3(14), 209-222.

[5] Adeolu, B. A., Taiwo, A., \& Ayanbimipe, M., A. (2005). The influence of advertising and consumer brand preference. Journal of Social Science, 10(1), 9-16. https://doi.org/10.1080/09718923.2005.11892453.

[6] Afzal, S., Chandio, A. M., Shaikh, S., Bhand, M., \& khuhro, A. K. (2013). Factors behind brand switching in cellular networks. International Journal of Asian Social Science, 3, 299-307.

[7] Agu, A. O., Obi, C. O., \& Afamefuna, E. M (2020). Determinants of telecommunications sector contributions to domestic output in Nigeria. International Journal of Economics, Commerce and Management, United Kingdom, VIII(4), 56-77.

[8] Amole B, Adebiyi S \& Awolaja A (2012). Corporate social responsibility and profitability of Nigeria banks. Research Journal of Finance and Accounting, 3(1), 6-17.

[9] Arens, W. F. (1996). Contemporary Advertising. Richard/Irwin USA: Times Mirror Higher Education Group Inc., Company.

[10] Barney, J. B. (1991). Firm Resources and Sustained Competitive Advantage. Journal of Management, 17(1), 99-120. https://doi.org/10.1177/014920639101700108.

[11] Baohong, S., Scott, A. N. \& Kannan, S. (2003). Measuring the impact of promotions on brand switching when consumers are forward looking. Journal of Marketing Research, 40(4), 389-405. https://doi.org/10.1509/jmkr.40.4.389.19392.

[12] Belch, G. E. \& Belch, M. A. (2001) Advertising and promotion: an integrated marketing communications perspective, (5th edn). New York: Irwin/McGraw-Hill.

[13] Brown, R. (1974). Sales response to promotions and advertising. Journal of Advertising Research, 14, 33-38

[14] Doob, A., Carlsmith, J., Freedman, J., Laudauer, T., \& Tom, S. (1969). Effect of initial selling price on subsequent sales. Journal of Personality and Social Psychology, 11, 345-350. https://doi.org/10.1037/h0027415.

[15] Ezinne, N., Igomu, J. A., Apochi, S., \& Igomu, I. (2017). Corporate planning and performance of selected telecommunication companies in Makurdi, Benue State. International Journal of Business and Management Invention, 6(12), 44-54.

[16] Ezirim, A. C., Nwokah, N. G., Udo, I. M., \& Worha, Y. A. (2004). Principles and practice of marketing: elements of marketing, practice of marketing, legal aspects of marketing and international application to marketing. Owerri: JESO International (NIG).

[17] Grigoriou, N., Majumdar, A., \& Lie, L., (2018). Drivers of brand switching behavior in mobile telecommunications. Athens Journal of Mass Media and Communications, 4, 7-28. https://doi.org/10.30958/ajmmc.4.1.1.

[18] Gujarati, D. N. (2013) Basic Business Econometrics. Tata: McGraw-Hill Education, Noida.

[19] Hodgson, V. L., (2004). Linking marketing to shareholder value in listed and non-listed markets (Unpublished PhD Thesis). Griffith University. Available at: http://hdl.handle.net/10072/367168. (Accessed 22 September 2020).

[20] Idamoyibo, H. R. (2017). Performance of communication networks and brand switching amongst students of the delta state university, abraka. (Unpublished Master Dissertation). Delta State University, Abraka, Nigeria.

[21] International Telecommunication Union (ITU) (2020). Economic impact of covid-19 on digital infrastructure. Report of an Economic Experts GSR20 Round table discussion Paper, 1-35. June, 26. International Telecommunication Union Place des Nations CH-1211 Geneva, Switzerland.

[22] Jothi, P. S., Neelamalar, M., \& Prasad, R. S. (2011). Analysis of social networking sites: a study on effective communication strategy in developing brand communication. Journal of Media and Communication Studies, 3, 234-242.

[23] Keffas, G., \& Olulu-Briggs, O. (2011). Corporate social responsibility: how does it affect the financial performance of banks? Journal of Management and Corporate Governance, 3(3), 8-26.

[24] Lamb, C. W., Hair, J. F., \& McDaniel, C. (2004). Marketing, (7th edn). Canada: South-Western.

[25] Nigeria Communications Commission. Subscriber statistics. The federal republic of Nigeria. April-July, 2017. Available at: https://www.ncc.gov.ng/statistics-reports/subscriber-data. (Accessed 22 September 2020).

[26] Nigeria Communications Commission (2005). "Trends in Telecommunications in Nigeria" (2003-2004). Abuja. Available at: http//www.ncc/gov.ng. (Accessed 19 September 2020).

[27] Nkordeh, N., Bob-Manuel, I. \& Olowononi, F. (2017). The Nigerian telecommunication industry: analysis of the first fifteen years of the growths and challenges in the GSM market (2001-2016). Proceedings of the World Congress on Engineering and Computer Science, 1, October 25-27, 2017, USA: San Francisco.

[28] Obiekwe, C. V. (2012). The impact of advertising and promotion on preference for different models of mobile phones by the youths in Enugu. A case study of students in higher institutions in Enugu metropolis (Unpublished Master's Research Paper). University of Nigeria, Nigeria.

[29] Oghojafor, B. E. A., Ladipo, K. A. P., Ighomereho, O. S. Odunewu, A. V (2014). Determinants of customer satisfaction and loyalty in the Nigerian telecommunications industry. British Journal of Marketing Studies, 2(5), 67-83.

[30] Ogungbade, I. O. (2021). Corporate social responsibility and financial performance of deposit money banks: A new evidence from Nigeria. International Journal of Accounting and Economics Studies, 9(1), 1-7.

[31] Onah, J. O., \& Thomas, M. J. (2004) Marketing Management: Strategies and Cases, (2nd edn). Institute for Development Studies, University of Nigeria, Enugu Campus, Enugu.

[32] Olotewo, J. (2017). Analyzing the moderating effect of customer loyalty on long run repurchase intentions. Africa Journal of Marketing and Management, 9(3), 25-34. DOI:10.5897/AJMM2016.0505.

[33] Olumoko, T. A., Abass, O. A., \& Dansu, S. F (2012). The roles of personal selling in enhancing clients' satisfaction in Nigeria insurance market. Journal of Emerging Trends in Economics and Management Sciences (JETEMS), 3(2), 147-152.

[34] Onwumere, J. U. J. (2009). Business and economic research methods, (2nd edn). Enugu: Vougasen Limited.

[35] Pan, X., Sha, J., Zhang, H. \& Ke, W. (2014). Relationship between corporate social responsibility and financial performance in the mineral industry: Evidence from Chinese mineral firms, Sustainability, 6, 4077-4101. https://doi.org/10.3390/su6074077.

[36] Penrose, E. T. (1959). The theory of growth of the firm. Oxford: Oxford University Press.

[37] Porter, M. (1980). Competitive strategy: techniques for analyzing industries and competitors. New York: The Free Press.

[38] Salisu, U., Ibrahim, E. Y (2014). Institutions, telecommunications and economic performance in Nigeria. Journal of Economics and Sustainable Development, 5(18), 110-122. 
[39] Scott, C. (1976). Effects of trial and incentives on repeat purchase behaviour. Journal of Marketing Research, 13, 263-269. https://doi.org/10.1177/002224377601300307.

[40] Shehzad, A. M., Moosavi, D. (3013). Factor influencing the cell phone brand loyalty of Swedish generation y. (Unpublished Master Thesis). Mälardalen University. The School of Business, Society and Engineering, Västerås, Sweden.

[41] Susanti, S. (2015). Modeling brand switching of blackberry smartphone using logistic regression. Available at: http://icehm.org/upload/3197ED0315106.pdf. (Accessed 27 June 2018).

[42] Uadiale, O. M., \& Fagbemi, T. O. (2012). Corporate social responsibility and financial performance in developing economies: The Nigerian experience. The 2011 New Orleans International Academic Conference.UK Evidence from Disaggregate Measures, Financial Management, 35, 97-116.

[43] Uppu, V. A. R., Pujari, V. C. S. M. R., \& Raghava, R. G. (2016). Brand switching behavior in Indian wireless telecom service market. Journal of Marketing Management, 4, 2, 100-109. https://doi.org/10.15640/jmm.v4n2a9.

[44] Wissink, R. B. A. (2012). Testing the relation between corporate social performance and corporate financial performance. (Unpublished Master Thesis). University of Twente.

[45] Wooldridge, J. M. (2010). “Econometric Analysis of Cross Section and Panel Data”, (2nd edn). Cambridge: MIT Press Books, the MIT Press, $1(0262232588)$. 